\title{
IMPLEMENTASI STANDAR PROSES DALAM KURIKULUM 2013 DI SEKOLAH DASAR
}

\section{Ndaru Mukti Oktaviani, Isnaini Wulandari}

ndaru.mukti.oktaviani@uniku.ac.id, Isnaini.wulandari@uniku.ac.id

Pendidikan Guru Sekolah Dasar, Fakultas Keguruan dan Ilmu Pendidikan,

Universitas Kuningan, Indonesia

Submitted:

28 September 2019

$28^{\text {th }}$ September 2019

Accepted:

17 Oktober 2019

$17^{\text {th }}$ October 2019

Published:

22 Oktober 2019

$22^{\text {th }}$ October 2019
Abstract: The curriculum 2013 is one of the policies of the Indonesian government in improving the quality of human resources through education that is adjusted to the needs of the community. Changes in the learning process in the curriculum 2013 have an impact on the readiness of teachers to implement it. Based on the results of the FGD conducted with elementary school teachers in the Kuningan region, it was stated that most of the teachers still had difficulties in implementing the learning process that was in accordance with the learning process of the 2013 curriculum. This statement should be explored further on what were the causes of teacher difficulties in applying the learning process in accordance with the curriculum 2013. Therefore it is necessary to conduct research on the implementation of standard processes in the curriculum 2013 in elementary schools. The research method used in this study is case study. The study was conducted at public elementary schools located in Kuningan Regency, namely $S D$ Negeri Dukuhdalem, Japara District, SD Negeri 1 Manislor, Jalaksana District, and SD Negeri 1 Purwawinangun, Kuningan District. There are two types of research instruments used, namely observation sheets and interview guides. The results of the study note that the main obstacle in carrying out the syllabus in the curriculum 2013 is the lack of socialization in changing syllabus content, teachers have difficulty in making lesson plans, especially to include activities that are in accordance with the scientific approach, there is a gap between the material needed and the source of material in the book. provided, in the classroom management aspect the obstacle faced is the teacher's lack of readiness to follow changes in the learning process in the curriculum 2013, the teacher is still unable to carry out the demands of the learning process that is in accordance with the curriculum 2013 in the assessment process, most teachers complained about the complexity of the assessment process. The obstacle often faced by teachers was that the assessment instruments were still limited.

Keywords: standards process, curriculum 2013, elementary school

Abstrak: Kurikulum 2013 merupakan salah satu kebijakan pemerintah Indonesia dalam meningkatkan kualitas sumber daya manusia melalui pendidikan yang disesuaikan dengan kebutuhan masyarakat. Perubahan proses pembelajaran dalam kurikulum 2013 berdampak pada kesiapan guru dalam menerapkannya. Berdasarkan hasil FGD yang dilaksanakan dengan guru sekolah dasar yang ada di wilayah Kuningan dinyatakan bahwa sebagian besar guru masih mengalami kesulitan dalam menerapkan proses pembelajaran yang sesuai dengan proses pembelajaran kurikulum 2013. Pernyataan ini harus ditelusuri secara lebih lanjut mengenai apa saja yang menjadi penyebab kesulitan guru dalam menerapkan proses pembelajaran yang sesuai dengan kurikulum 2013. Oleh karena itu perlu dilakukan penelitian mengenai implementasi standar proses dalam kurikulum 2013 di sekolah dasar. Metode penelitian yang digunakan dalam penelitian ini adalah case study. Penelitian dilakukan di SD Negeri yang berada di wilayah Kabupaten Kuningan, yaitu SD Negeri Dukuhdalem, Kecamatan Japara, SD Negeri 1 Manislor, Kecamatan Jalaksana, dan SD Negeri 1 Purwawinangun, Kecamatan Kuningan. Terdapat dua jenis instrumen penelitian yang digunakan yaitu lembar observasi dan panduan wawancara. Hasil penelitian diketahui bahwa hambatan utama dalam menjalankan silabus dalam kurikulum 2013 adalah kurangnya sosialisasi dalam perubahan isi silabus, guru mengalami kesulitan dalam pembuatan RPP terutama untuk memasukkan kegiatan yang sesuai dengan scientific approach, terdapat kesenjangan antara materi yang dibutuhkan dengan sumber materi yang ada pada buku yang disediakan, pada aspek pengelolan kelas kendala yang dihadapi adalah kekurangsiapan guru untuk mengikuti perubahan proses pembelajaran dalam kurikulum 2013, guru masih belum mampu menjalankan tuntutan proses pembelajaran yang sesuai dengan kurikulum 2013. Hal ini disebabkan karena guru menganggap metode pembelajaran dengan proses berpikir $5 M$ bersifat prosedural dan pada proses penilaian sebagian besar guru mengeluhkan rumitnya proses penilaian kendala yang sering dihadapi oleh guru adalah instrumen penilaiannya masih sangat terbatas.

Kata Kunci: standar proses, kurikulum 2013, sekolah dasar
CITATION
Oktaviani, N.M., \& Wulandari, I. (2019). Implementasi Standar Proses dalam Kurikulum 2013 di Sekolah Dasar. Primary: Jurnal Pendidikan Guru Sekolah Dasar, 8(2), 180-187. DOI: http://dx.doi.org/10.33578/jpfkip.v8i2.7960. 


\section{PRIMARY : JURNAL PENDIDIKAN GURU SEKOLAH DASAR \\ Volume 8 Nomor 2 Oktober 2019 \\ DOI : http://dx.doi.org/10.33578/jpfkip.v8i1.7960 \\ ISSN : 2303-1514 | E-ISSN : 2598-5949 \\ https://primary.ejournal.unri.ac.id/index.php/JPFKIP}

\section{PENDAHULUAN}

Kurikulum 2013 merupakan salah satu kebijakan pemerintah Indonesia dalam meningkatkan kualitas sumber daya manusia melalui pendidikan yang disesuaikan dengan kebutuhan masyarakat. Alasan pentingnya penerapan Kurikulum 2013 adalah bahwa generasi muda Indonesia perlu disiapkan dalam kompetensi sikap, keterampilan, dan pengetahuan (Kustijono \& Wiwin, 2014). We must remember that intelligence is not enough. Intelligence plus character-that is the goal of true education (Luther King, 1947).

Pada proses pengimplementasian kurikulum 2013 diharapkan siswa mampu secara mandiri meningkatkan dan menggunakan pengetahuannya, mengkaji, menganalisis, dan mempersonalisasikan nilai-nilai karakter serta akhlak mulia sehingga terwujud dalam perilaku sehari-hari (Saputri \& Mawardi, 2017). Sehingga yang dijadikan sebagai tujuan utama pada kurikulum 2013 adalah pengembangan ranah sikap, pengetahuan, dan keterampilan yang seimbang pada diri peserta didik.

Proses penerapan kurikulum 2013 berimbas secara langsung pada pelaksana utama di lapangan yaitu guru. Kondisi ini mendesak pemerintah untuk memastikan kesiapan guru dalam mengimplementasikan kurikulum 2013 melalui pelatihan yang telah disiapkan. Karena kunci keberhasilan kurikulum ini juga dipengaruhi oleh persepsi guru tentang hambatan dan dukungan implementasi Kurikulum 2013 (Krissandi \& Rusmawan, 2015). Pelatihan implementasi kurikulum yang bagi guru merupakan sebuah kebutuhan, karena dengan adanya perubahan dokumen seperti halnya kurikulum 2013 memerlukan pemahaman secara

\section{METODE PENELITIAN}

Sukmadinata (2010) menerangkan bahwa penelitian kualitatif adalah suatu penelitian yang digunakan untuk mendeskripsikan dan menganalisis fenomena, peristiwa, aktivitas sosial, sikap, kepercayaan, persepsi, pemikiran orang secara individu maupun kelompok. Dengan demikian, jenis penelitian ini cocok digunakan untuk mengungkap kasus permasalahan yang komprehensif bagi pemangku kepentingan pelaksana kurikulum, seperti guru, kepala sekolah, pengawas, dan penjaminan mutu pendidikan di lapangan (Sutjipto, 2016). Hal-hal tersebut dilakukan oleh pemerintah tentunya bertujuan agar ketika Kurikulum 2013 dilaksanakan tidak memiliki kendala dan halangan yang berarti bagi para guru sebagai pelaksana di lapangan.

Perubahan standar nasional pendidikan juga mempengaruhi penerapan kurikulum 2013 salah satunya pada standar proses. Proses pembelajaran pada Kurikulum 2013 untuk semua jenjang dilaksanakan dengan menggunakan pendekatan ilmiah (saintifik). Langkah-langkah pendekatan ilmiah (scientific appoach) dalam proses pembelajaran meliputi: menggali informasi melaui pengamatan, bertanya, percobaan, kemudian mengolah data atau informasi, menyajikan data atau informasi, dilanjutkan dengan menganalisis, menalar, kemudian menyimpulkan, dan mencipta (Subagiyo, L. \& Safrudiannur, 2014).

Perubahan proses pembelajaran dalam kurikulum 2013 berdampak pada kesiapan guru dalam menerapkannya. Berdasarkan hasil FGD yang dilaksanakan dengan guru sekolah dasar yang ada di wilayah Kuningan dinyatakan bahwa sebagian besar guru masih mengalami kesulitan dalam menerapkan proses pembelajaran yang sesuai dengan proses pembelajaran kurikulum 2013. Pernyataan ini harus ditelusuri secara lebih lanjut mengenai apa saja yang menjadi penyebab kesulitan guru dalam menerapkan proses pembelajaran yang sesuai dengan kurikulum 2013. Oleh karena itu, dilakukan penelitian mengenai implementasi standar proses dalam kurikulum 2013 di sekolah dasar.

dihadapi guru sekolah dasar dalam implementasi Kurikulum 2013.

Desain penelitian yang digunakan mengacu pada langkah-langkah penelitian deskriptif jenis studi kasus. Studi kasus yang dijadikan fokus kajian adalah permasalahan yang dihadapi guru di sekolah dasar dalam implementasi Kurikulum 2013. 
Berkenaan dengan penelitian ini sumber data dan teknik pengumpulan data yang digunakan sebagai berikut:

1. Untuk mendapatkan data tentang perencanaan pembelajaran dalam implementasi Kurikulum 2013, sumber datanya adalah guru dan siswa. Teknik pengumpulan data yang digunakan adalah wawancara dan pengamatan. Wawancara dilakukan kepada guru yang dipilih secara acak, sedangkan pengamatan dilakukan dengan mengamati proses kegiatan pembelajaran di kelas.

2. Untuk mendapatkan data tentang proses pembelajaran dalam implementasi kurikulum 2013, sumber datanya adalah guru dan siswa. Teknik pengumpulan data yang digunakan adalah wawancara dan pengamatan. Wawancara dilakukan kepada guru yang dipilih secara acak, sedangkan pengamatan dilakukan dengan mengamati proses kegiatan pembelajaran di kelas.

3. Untuk mendapatkan data tentang penilaian pembelajaran dalam implementasi Kurikulum 2013, sumber datanya adalah guru dan siswa.
Teknik pengumpulan data yang digunakan adalah wawancara dan pengamatan. Wawancara dilakukan kepada guru yang dipilih secara acak, sedangkan pengamatan dilakukan dengan mengamati proses kegiatan pembelajaran di kelas.

Penelitian dilakukan di SD Negeri yang berada di wilayah Kabupaten Kuningan, yaitu SD Negeri Dukuhdalem, Kecamatan Japara, SD Negeri 1 Manislor, Kecamatan Jalaksana, dan SD Negeri 1 Purwawinangun, Kecamatan Kuningan. Dalam penelitian ini untuk menghindari waktu penelitian yang berlarut-larut, maka penelitian merencanakan waktu penelitian pada bulan Agustus sampai Desember 2018.

Intrumen yang digunakan dalam penelitian ini yaitu lembar observasi dan panduan wawancara. Lembar observasi digunakan untuk mengamati siswa dan guru dalam proses pembelajaran dalam rangka mengungkap data berkenaan dengan faktor-faktor permasalahan yang dihadapi guru sekolah dasar dalam implementasi Kurikulum 2013. Berikut pedoman observasi yang digunakan dalam pengambilan data:

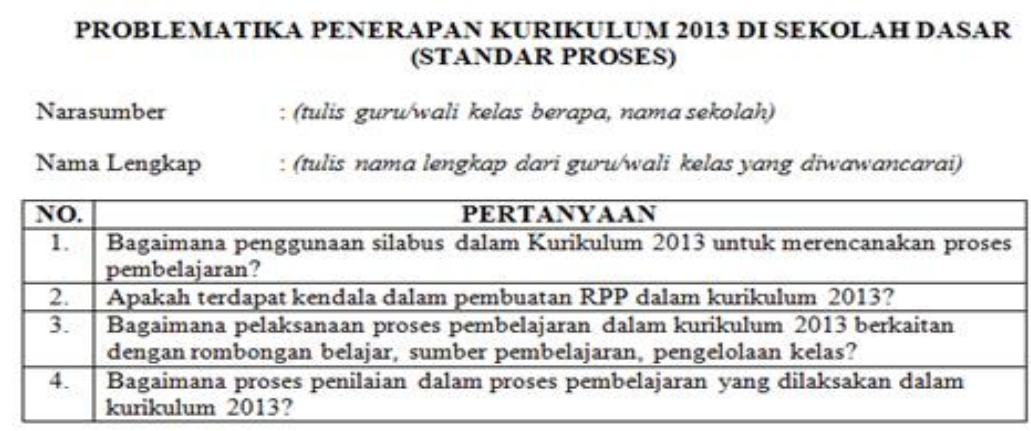

Gambar 1. Pedoman Observasi

Sedangkan pedoman wawancara digunakan untuk mengungkap data yang berasal dari siswa dan guru berkenaan dengan standar proses yang dihadapi guru sekolah dasar dalam implementasi Kurikulum 2013. Berikut pedoman wawancara yang digunakan dalam pengambilan data: 


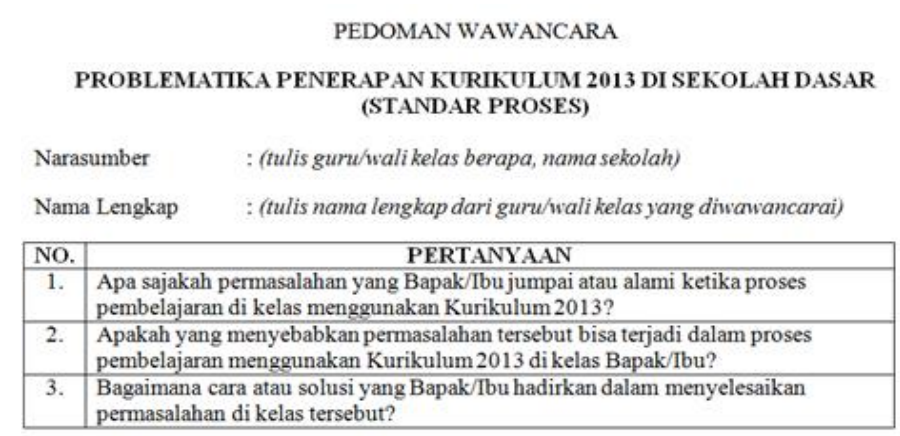

Gambar 2. Pedoman Wawancara

Teknik analisis data yang digunakan dalam penelitian ini adalah teknik analisis data kualitatif, mengikuti konsep yang diberikan oleh Miles and Huberman dan Spradley. Miles and Huberman (1984) mengemukakan bahwa aktifitas dalam analisis data kualitatif dilakukan secara interaktif dan berlangsung secara terus menerus pada setiap tahapan penelitian sehingga sampai tuntas, dan datanya sampai jenuh. Kegiatan dalam pengumpulan data, yaitu: 1) data reduction, yang mana data yang terlalu banyak perlu untuk difokuskan pada hal-hal yang pokok; 2) data display, yang mana data perlu disajikan agar tersusun pola hubungan dan mudah untuk dipahami; 3) dan conclusion drawing/verifying, yang mana menjawab rumusan masalah awal disesuaikan dengan perkembangan selama penelitian. Kegiatan pengumpulan data digambarkan sebagai berikut:

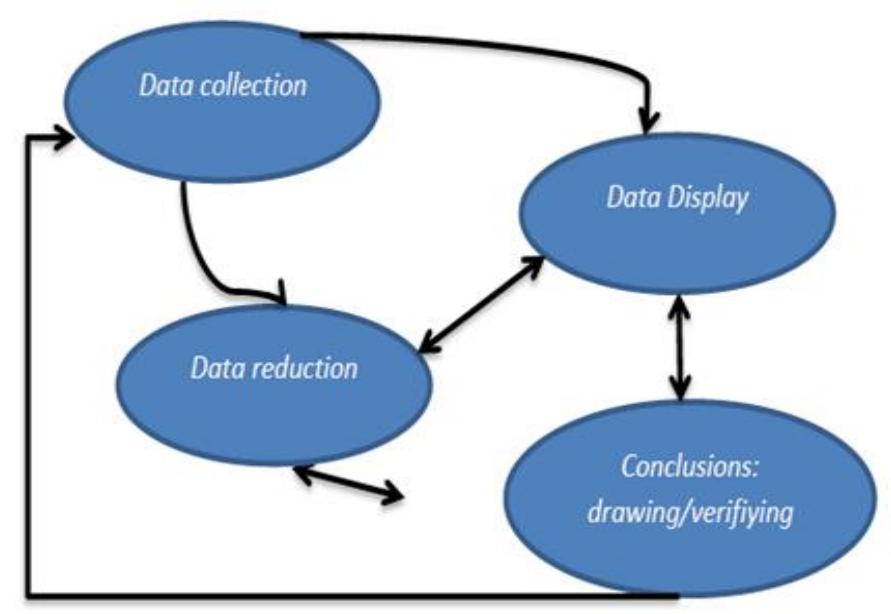

Gambar 3. Komponen Analisis Data (Miles and Huberman, 1984)

Dalam penelitian ini pengujian kredibilitas data penelitian dilakukan dengan cara:

1. Perpanjangan pengamatan. Perpanjangan pengamatan dilakukan sampai data yang diperoleh dirasa memadai dan kredibel.

2. Meningkatkan ketekunan. Meningkatkan ketekunan berarti melakukan pengamatan secara lebih mendalam, cermat dan berkesinambungan. Pengujian kredibilitas ini dilakukan dengan cara peneliti membaca seluruh catatan hasil penelitian secara cermat, sehingga dapat diketahui kesalahan dan 
kekurangannya.

3. Triangulasi dilakukan dengan cara triangulasi teknik, sumber data dan waktu. Triangulasi teknik dilakukan dengan cara menanyakan hal yang sama dengan teknik yang berbeda, yaitu dengan cara wawancara, observasi dan dokumentasi. Triangulasi sumber, yaitu dilakukan dengan cara menanyakan hal yang sama terhadap sumber yang berbeda, dalam hal ini adalah guru dan siswa yang dipilih secara acak. Triangulasi waktu artinya pengumpulan data dilakukan pada berbagai kesempatan.

\section{HASIL DAN PEMBAHASAN}

Standar proses berfungsi sebagai alat untuk mencapai tujuan dari pendidikan. Secara lebih lanjut dalam Permendikbud No 22 Tahun 2016 menyatakan bahwa standar proses adalah kriteria mengenai pelaksanaan pembelajaran pada satuan pendidikan untuk mencapai Standar Kompetensi Lulusan. Hal ini menggambarkan bahwa meskipun standar kompetensi lulusan sudah dibuat dengan ideal, dan standar isi sudah dibuat dengan sangat lengkap, tanpa diimplementasikan dengan baik pada standar proses maka, semua akan menjadi sia-sia. Ada tiga hal yang diamati dalam standar proses pembelajaran, yaitu yang pertama perencanaan pembelajaran (RPP, Silabus), proses pembelajaran (rombongan belajar, sumber pembelajaran, pengelolaan kelas, pelaksanaan pembelajaran) dan penilaian hasil pembelajaran (Indrawan, S., 2014).

Pada pelaksanaannya silabus dalam kurikulum 2013 menurut subyek yang diwawancarai menyampaikan bahwa silabus dalam Kurikulum 2013 mudah dipahami. Kendala yang dihadapi dalam menerapkan silabus Kurikulum 2013 diungkapkan oleh subyek SH dalam wawancara sebagai berikut:

Yang jadi kendala dalam silabus kurikulum 2013 itu adalah kadang-kadang ynag namanya silabus pasti ada revisi dibagian KD, tapi minim pemberitahuan sehingga kita yang menjadi guru harus menyesuaikan dengan buku pegangan yang baru (Wawancara SH, 20 Mei 2019).
4. Diskusi teman sejawat dilakukan dengan mendiskusikan hasil penelitian yang masih bersifat sementara dengan rekan-rekan dosen pendidikan dasar yang mengampu mata kuliah kurikulum.

5. Analisis kasus negatif adalah kasus yang tidak sesuai atau berbeda dengan hasil penelitian hingga pada saat tertentu.

6. Member check (Pengecekan anggota). Dalam hal ini member check dilakukan dengan mendiskusikan temuan-temuan hasil penelitian dengan sumber data yaitu guru.

Kondisi ini memberikan gambaran bahwa yang menjadi hambatan utama dalam menjalankan silabus kurikulum 2013 adalah kurangnya sosialisasi dalam perubahan isi silabus. Hal ini tentunya menjadi sebuah permasalahan bagi guru yang dirasakan oleh sebuah subyek penelitian karena bagaimanapun mereka menggunakan silabus sebagai pedoman dalam mengembangkan perencanaan pembelajaran yang tepat. Ketika tidak dilakukan sosialisasi secar merata semua subyek merasa kesulitan dalam membuat perencanaan pembelajaran yang baik.

Rencana pelaksanaan pembelajaran merupakan langkah yang harus ditempuh seorang guru untuk merancang pengalaman pembelajaran yang akan diterima oleh peserta didik. Sebagian besar subyek mengungkapkan bahwa mereka mengalami kesulitan dalam pembuatan RPP terutama untuk memasukkan kegiatan yang sesuai dengan scientific approach. Hal ini disampaikan oleh subyek SH dalam wawancara sebagai berikut:

Kalau membuat RPP itu yang sulit adalah memasukkan $5 \quad M \quad$ (Menanya, Menganalisis, mengamati, mengumpulkan informasi dan mengkomunikasikan (Wawancara SH, 20 Mei 2019).

Kesulitan ini dikarenakan guru mematok kegiatan $5 \mathrm{M}$ dalam bentuk prosedural pengajaran, bukan sebagai proses berpikir yang dapat dilakukan oleh peserta didik kapan saja selama proses pembelajaran. 
Proses pembelajaran melibatkan banyak hal mulai dari rombongan belajar, sumber pembelajaran, pengelolaan kelas serta pelaksanaan pembelajaran. Untuk rombongan belajar atau sebagian besar guru menyebutkan dengan kelas tidak terdapat permasalahn yang berarti dalam proses pengimplementasiannya. Hal ini berbeda dengan sumber belajar dimana sebagaian besar guru mengeluhkan sumber belajar yang digunakan masih kurang lengkap materinya sehingga mereka memilih menggunakan sumber belajar dari kurikulum sebelumnya. Hal ini diungkapkan oleh subyek MT dalam hasil wawancara sebagai berikut:

Kalau ibu mengatasi masalah seperti yang dijelaskan tentang materi pembelajaran pada kurikulum 2013 kurang luas, kepaksa ibu sering menggunakan buku lain yang sesuai dengan materi yang diajarkan, misalnya menggunakan kembali bukubuku kurikulum KTSP (Wawancara MT, 11 Mei 2019).

Pernyataan ini memberikan gambaran bahwa sumber belajar dalam kurikulum 2013 belumlah memadai, kondisi ini juga di sampaikan oleh sebagian besar narasumber lain. Pada dasarnya sumber belajar juga dapat diperoleh dari sekitar kita, di samping itu lingkungan juga dapat digunakan dalam kegiatan belajar mengajar (Lilawati, J., 2017). Akan tetapi berdasarkan hasil wawancara dan pengamatan dalam proses pembelajaran sebagian besar subyek guru menganggap bahwa yang dinyatakan sebagi sumber belajar hanyalah buku ajar yang telah disediakan, kondisi ini memunculkan kesenjangan antara materi yang dibutuhkan dengan sumber materi yang ada pada buku yang disediakan.

Pada aspek pengelolan kelas kendala yang dihadapi adalah kekurangsiapan guru untuk mengikuti perubahan proses pembelajaran dalam kurikulum 2013. Hal ini diungkapkan oleh subyek ES dalam hasil wawancara sebagai berikut

Belum mampu diterapkan secara optimal apalagi saya mengajar anak kelas I baru lima menit masuk kelas sudah lari-larian kadang juga ada yang becanda terus nangis aturan dari pemerintah di kurikulum 2013 itu justru malah jadi ribet apalagi untuk anak kelas rendah (Wawancara ES, 11 Mei 2019).

Subyek ES memberikan gambaran mengenai kesulitan subyek untuk mengkondisikan kelas sesuai dengan proses pembelajaran yang diinginkan dalam kurikulum 2013. Berdasarkan pengamatan dalam proses pembelajaran diketahui bahwa subyek ES pada dasarnya sudah berusaha menggunakan metode pembelajaran yang menyenangkan namun tetap pada akhirnya kembali pada sistem direct instruction karena kesulitan mengelola kelas dengan metode lain yang melibatkan siswa dalam proses pembelajaran.

Kesulitan dalam melaksanakan proses pembelajaran juga disampaikan oleh subyek $\mathrm{SH}$ dalam wawancara sebagai berikut:

\section{Standar proses merupakan sebuah tahapan langkah-langkah untuk memberikan pembelajaran di dalam kelas, dengan harapan proses pendidikan bias berjalan efektif, efisien serta inovatif. Akan tetapi, proses pembelajaran K13 tuntutan dari pemerintah tersebut belum mampu diterapkan secara optimal di sekolah, kendalanya ialah siswa kerap merasa jenuh dan kurang bersemangat ketika masuk kelas kembali sesudah jam istirahat pertama (Wawancara SH, 20 Mei 2019).}

Pernyataan subyek SH memberikan gambaran bahwa sebagian guru masih belum mampu menjalankan tuntutan proses pembelajaran yang sesuai dengan kurikulum 2013. Hal ini disebabkan karena guru menganggap metode pembelajaran dengan proses berpikir 5M (mengamati, menanya, mengumpulkan informasi atau mencoba, mengasosiasi, mengomunikasikan) bersifat prosedural dan mekanistik sehingga membelenggu ruang kreatif (Kemendikbud, 2014). Hal ini nampak dalam observasi yang menunjukkan bahwa guru berusaha mengurutkan semua proses pembelajaran dengan langkah $5 \mathrm{M}$, sehingga terkesan $5 \mathrm{M}$ menjadi suatu langkah pembelajaran yang harus berurutan. Padahal pada pelaksanaannya guru diberikan ruang kreatif untuk 
memiliki otonomi dalam proses pembelajaran yang mendorong pembelajaran yang aktif. Secara lebih lanjut akan lebih baik bagi guru apabila memandang proses berpikir $5 \mathrm{M}$ sebagai suatu proses berpikir yang perlu ditumbuhkan dan dibiasakan bagi peserta didik, bukan sebagai sintak atau langkah prosedural semata.

Pada proses penilaian sebagian besar guru mengeluhkan rumitnya proses penilaian kendala yang sering dihadapi oleh guru adalah instrumen penilaiannya masih sangat terbatas. Hal ini diungkapkan oleh subyek $\mathrm{SH}$ dalam wawancara sebagai berikut:

Penilaian pembelajaran K13 secara keseluruhan sudah mampu diterapkan hanya saja dalam penerapannya terdapat kendala seperti penilaian pengetahuan dengan bentuk penugasan indicator untuk membuat instrument penilaiannya masih sangat terbatas sehingga menyulitkan bagi guru untuk menentukan siswa mana yang nilainya sudah melebihi KKM serta minimnya sosialisasi dari pemerintah dalam membuat instrument penilaian autentik yang baik dan benar pada kurikulum 2013 (Wawancara SH, 20 Mei 2019).

\section{SIMPULAN DAN REKOMENDASI}

Berdasarkan hasil penelitian dan pembahasan dapat disimpulkan sebagai berikut:

1. Hambatan utama dalam menjalankan silabus dalam kurikulum 2013 adalah kurangnya sosialisasi dalam perubahan isi silabus.

2. Guru mengalami kesulitan dalam pembuatan RPP terutama untuk memasukkan kegiatan yang sesuai dengan scientific approach.

3. Terdapat kesenjangan antara materi yang dibutuhkan dengan sumber materi yang ada pada buku yang disediakan.

4. Pada aspek pengelolan kelas kendala yang dihadapi adalah kekurangsiapan guru untuk mengikuti perubahan proses pembelajaran dalam kurikulum 2013.

5. Guru masih belum mampu menjalankan tuntutan proses pembelajaran yang sesuai
Kondisi ini tentunya memberikan gambaran bahwa guru dilapangan belum dapat melaksanakan proses penilaian pembelajaran secara optimal dikarenakan faktor kemampuan yang belum memadai dan merasa masih kurangnya pelatihan serta sosialisasi dalam meningkatkan kemampuan penilaian proses pembelaran Kurikulum 2013.

Kendala lain yang dihadapi dalam pelaksanaan penilaian dalam proses pembelajaran dalam kurikulum 2013 adalah dalam banyaknya aspek yang harus dinilai yang dirasa oleh sebagian subyek membingungkan dan terlalu banyak. Hal ini diungkapkan oleh subyek AN dalam hasil wawancara sebagai berikut:

Menurut ibu cara penilaiannya itu masih belum jelas bagaimana cara penilaiannya soalnya kan banyak yang harus dinilai (Wawancara AN, 22 Mei 2019).

Pernyataan subyek memberikan gambaran bahwasannya sebagian besar guru dalam proses penilaian pembelajaran merasa terbebani dengan semua perangkat penilaian yang disediakan terlalu banyak. Penilaian dalam kurikulum 2013 mencakup penilaian sikap, keterampilan, dan pengetahuan sehingga bagi guru mereka merasa terbebani dalam proses penilaian.

dengan kurikulum 2013. Hal ini disebabkan karena guru menganggap metode pembelajaran dengan proses berpikir $5 \mathrm{M}$ bersifat prosedural.

6. Pada proses penilaian sebagian besar guru mengeluhkan rumitnya proses penilaian kendala yang sering dihadapi oleh guru adalah instrumen penilaiannya masih sangat terbatas.

Berdasarkan simpulan di atas, maka dapat peneliti rekomendasikan beberapa hal yaitu guru harus terus mengupdate informasi tentang perubahan isi silabus, guru harus memahami cara mengimplementasikan scientific approach kedalam kegiatan di RPP serta mencari sumber materi pembelajaran agar materi pembelajaran dapat terpenuhi. 


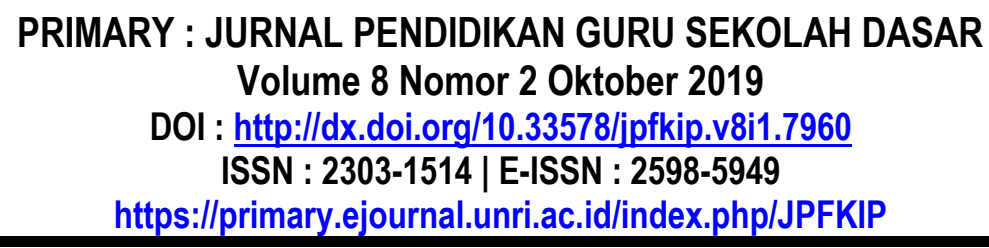

\section{DAFTAR PUSTAKA}

Permendikbud No 22 Tahun 2016 Tentang Standar Proses Pendidikan Dasar dan Menengah

Indrawan, S. (2014). "Implementasi Standar Proses Kurikulum 2013 di Jurusan Teknik Kendaraan Ringan Smk Negeri 1 Sedayu”. Skripsi Tidak Dipublikasikan. Universitas Negeri Yogyakarta

Lilawati, J. (2017). Analisis Pemanfaatan Sumber Belajar Dalam Proses Pembelajaran. Paper Presenter at the Prosiding Seminar Nasional, 2017, Fakultas Ilmu Sosial, Sumatra Utara, Medan, Indonesia. Universitas Negeri Medan.

Luther, K. (1947). The Purpose Of Education. Maroon Tiger. JR Paper Project

Retnawati, H. et, al (2017). Teachers' difficulties in implementing thematic teaching and learning in elementary schools. The New Educational Review, 201-212.

Kemendikbud. (2014). Konsep dan Implementasi Kurikulum 2013, Paparan Wakil Menteri Pendidikan dan Kebudayaan RI Bidang Pendidikan. Jakarta: Kementerian Pendidikan dan Kebudayaan.

Krissandi, A., \& Rusmawan. (2015, Oktober). Kendala Guru Sekolah Dasar dalam
Implementasi 2013. Cakrawala Pendidikan, 34(3), 457-467.

Kustijono, R., \& Wiwin, H. E. (2014). Pandangan Guru terhadap Pelaksanaan Kurikulum 2013 dalam Pembelajaran Fisika SMK di Kota Surabaya. Jurnal Pendidikan Fisika dan Aplikasinya (JPFA), IV(1), 1.

Miles, M.B., \& Huberman, A. M. (1984). Qualitative Data Analisys. Beverly Hills: Sage Publications.

Saputri, A., \& Mawardi. (2017). Pengembangan Desain Pembelajaran Tematik Integratif Berbasis Pendekatan Contextual Teaching and Learning (CTL) Kelas 4 Sekolah Dasar. Jurnal Ilmiah Pendidikan Dasar, 104-114.

Sutjipto. (2016). Pentingnya Pelatihan Kurikulum 2013 bagi Guru. Jurnal Pendidikan dan Kebudayaan, 1(26), 235-260.

Subagiyo, L. \& Safrudiannur (2014). Implementasi Kurikulum 2013 Pada Jenjang SD, SMP, SMA Dan SMK di Kalimantan Timur Tahun 2013/2014. Pancaran, 3(4), 131-144.

Sukmadinata, N. S. (2010). Metode Penelitian Pendidikan. Bandung: Remaja Rosdakarya. 